\title{
Pelestarian Lingkungan Candi dengan Memadukan Teknik Penanggulangan Banjir Studi Kasus Candi Blandongan di Kawasan Batujaya Kabupaten Karawang
}

\author{
Nuzuliar Rahmah \\ Jurusan Arsitektur, Fakultas Teknik Sipil dan Perencanaan, Universitas Trisakti \\ Jl. Kyai Tapa no 1 Jakarta Barat 021-5663232 ext 216 \\ Email: rnuzuliar@yahoo.co.id
}

\begin{abstract}
Abstrak
Pelestarian kawasan merupakan salah satu langkah untuk mempertahankan keberadaan benda- benda atau cagar budaya maupun peninggalan kepurbakalaan, tinggalan budaya yang menunjukan tingkat dan perkembangan peradaban nenek moyang yang memiliki nilai penting bagi sejarah, ilmu pengetahuan, pendidikan, agama, dan kebudayaan. Kawasan cagar budaya Batu Jaya secara geografis terletak di desa Telagajaya kecamatan Batujaya kabupaten Karawang. Kawasan ini memiliki sekitar empat puluh sembilan situs dimana salah satu situs yang sedang dikembangkan adalah candi Blandongan. Sebagai kawasan lindung, candi ini diharapkan berguna menjadi media pendidikan dan lokasi wisata budaya yang menarik buat masyarakat. Lingkungan situs terletak di daerah persawahan dan pemukiman dimana pada saat musim penghujan dan terjadi air laut naik menimbulkan permasalahan baru yaitu banjir yang dapat merusak elemen-elemen candi, sehingga perlu adanya teknik dalam menanggulangi pengelolaan lingkungan tersebut. Teknik pengendalian banjir yang diterapkan yaitu dengan membuat selokan dengan kedalaman 2 $m$, lebar $1 \mathrm{~m}$ dan membuat tanggul setinggi $0,5 \mathrm{~m}$ mengelilingi candi, serta membuat kolam penampungan air berukuran panjang $2 \mathrm{~m}$, lebar $2 \mathrm{~m}$ dan kedalaman 2,5 m. Dengan teknik pengendalian banjir ini dapat mencegah terjadinya banjir dan melindungi kerusakan-kerusakan situs candi ini. Pelestarian situs ini sangat penting mengingat situs ini merupakan tempat wisata dan peribadatan dan yang terpenting dengan adanya cagar budaya ini dapat meningkatkan pendapatan masyarakat disekitar nya dan Kabupaten Karawang
\end{abstract}

Kata Kunci : Pelestarian, situs, candi Blandongan, penanggulangan

\section{PENDAHULUAN}

Dari hasil penelitian para arkeologi kawasan Batujaya diperoleh gambaran mengenai empat strata budaya, yaitu strata perundagian, starata budaya peralihanstarata budaya masa Hindu-Buddha dan strata budaya pasca Hindu - Budha.

Berdasarkan hasil analisa penelitian stratigrafi tersebut dapat disusun kerangka kesejarahan dari masa perundagian hingga masa Hindia Belanda ditandai oleh kehadiran kerajaan tertua di pulau Jawa, Tarumanagara. Berdasarkan pertanggalan yang sudah diketahui oleh para arkeologi dari ciri peleografi masa Hindu-Budha di wilayah ini dimulai dari masa sekitar tahun 450 atau pertengahan abad ke-5. 
Di kawasan Batujaya masa ini ditandai pula oleh aktivitas pembangunan candi pembangunan percandian karena terdapat 49 candi yang masa dalam sejarahnya Dari sumber-sumber Tionghoa zaman Dinasti T'ang terjadi pertempuran antara kerajaan Tarumanagara dan kerajaan Sriwijaya yang terjadi pada abad ke 10 .Dari daerah sebelah barat bogor, di Jawa barat, yaitu di Kebon kopi (Kampung Muara). Dalam inskripsi tersebut telah mengembalikan kekuasaan kepada Raja Sunda. Berdasarkan sumber sumber sejarahnya dan hasil penelitian pakar arkeologi bahwa sejak sekitar abad ke-7 hingga abad ke-10 kerajaan Sriwijaya mempunyai hubungan erat dengan Nalanda, khususnya dalam perkembangan agama Buddha. Dengan demikian tidaklah mustahil unsur unsur nalanda yang mempengaruhi perkembangan agama dan kesenian kawasan Batujaya .

Bagaimana Agar pelestarian dan keberadaan cagar budaya tetap terjaga sehingga memerlukan langkah langkah yang harus diperhatikan. Hal inilah perlu adanya pemeliharaan bangunan candi dan lingkungannya.

\section{METODE PENELITIAN}

Obyek penelitian ini yaitu candi Blandongan yang berlokasi di Kawasan Batujaya, Kabupaten Karawang.

Dalam penelitian ini, metode yang dipergunakan yaitu dengan melakukan survey lapangan dan dengan menggunakan pendekatan-pendekatan arsitektural dan lingkungan sebagai berikut:

\subsection{Tinjauan Pelestarian secara Umum}

Pelestarian suatu kawasan cagar budaya dilakukan dengan mengikuti prinsip prinsip pelestarian sebagai berikut:

a. Perlindungan, melindungi candi dimana berupa bangunan dari masa lalu yang berfungsi sebagai tempat peribadatan agama Hindu dan Buddha. Dimana candi merupakan bangunan suci yang umumnya terdapat benda - benda dari batuan andesit. Kawasan cagar budaya batu Jaya terdapat susunan batu bata yang memiliki panjang dan lebarnya sangat berbeda dengan batu bata saat ini. Setelah diadakan penggalian ditemukan bangunan yang batu bata sudah runtuh, dan oleh para arkeologi disusun kembali sesuai dengan susunan sebuah candi. Karena keterbatasan biaya dan waktu maka situs baru dua candi yang dipugar dan masih banyak lagi yang masih terdapat didalam tanah masih berupa gundukan. 
b. Pengembangan, awalnya berupa unur (gundukan tanah) dan setelah diadakan kegiatan ekskavasi arkeologi kemudian perlu melakukan pengembangan kawasan agar dapat dimanfaatkan untuk kegiatan penelitian, pendidikan, keagamaan dan pariwisata, dan yang paling penting keberadaan kawasan cagar budaya ini dapat meningkatkan sosial budaya dan ekonomi bagi masyarakat batujaya pada khususnya dan karawang pada umumnya.

c. Pemanfaatan, kawasan cagar budaya juga dapat dimanfaatkan untuk kegiatan pariwisata dan kegiatan keagamaan dengan memperkenalkan kawasan batu jaga sebagai pusat peribatan agama hindu - budha. Hal ini terlihat banyaknya pengunjung yang datang untuk melakukan ritual keagamaan seperti pada perayaan waisak tiap tahun umat hindu baik yang domistik dan luar negeri, hal ini terlihat partisipasi para umat hindu dalam melestarikan dan menata kawasan ini.

\subsection{Tinjauan Arsitektural dan Lingkungan}

Tinjauan arsitektural yang dimaksudkan disini meliputi tinggalan artifak berupa sisa bangunan yang ditemukan dikawasan situs Batujaya yang berasal dari masa Hindu-Buddha adalah bangunan candi, bangunan profan dan tembok keliling.

Sedangkan tinjauan lingkungan yang dimaksudkan disini yaitu komponen lingkungan yang mempengaruhi upaya pelestarian candi yang meliputi antara lain topografi, tataguna lahan dan lainlain.

\section{HASIL DAN PEMBAHASAN}

Bentuk utuh bangunan candi yang ditemukan diseluruh kawasan Situs Batujaya sangat sulit untuk direkonstruksi secara pasti. Hal ini terutama disebabkan oleh sangat terbatasnya sisa-sisa bangunan yang dapat dijadikan peganganatau petunjuk kearah bentuk utuhnya adapun candi candi yang telah dilestarikan dan direnovasi adalah:

a. Candi Blandongan

Dari hasil penelitian pakar arkeologi candi jiwa diperkirakan badannya berupa stupa, yang berdiri dipermukaan kaki candi berdenah bujur sangkar. Bukti yang mendukung ke arah perkiraan itu diperoleh dari konstruksi atau pemasangan bata yang terdapat pada sisa bagian 
atas kaki bangunannya.Susunan pemasangan bata pada bagian atas kaki bangunan tersebut berpola melingkar konsentrik (lihat Gambar 2)

Temuan Bata melengkung dalam berbagai bentuk dan ukuran dalam jumlah yang cukup banyakpada reruntuhan canditersebut.Garis tengah bagian dasar susunan bata yang melingkar itu panjangnya sekitar 6 meter. Susunan bata yang melingkar konsentrik itu dibatasioleh susunan bata yang dipasang tegak (rolak) membentuk sebuah bujur sangkarberukuran sekitar 10 x $10 \mathrm{~m}$. Konstruksi seperti ini merupakan bentuk dasar sebuah bangunan stupa.Pada permukaan atas kaki candi di keempat sisi, dibagian luar struktur berbentuk bujur sangkar, tampak bentuk bentuk permukaan yang bergelombang keatas pada sudut sudut dan bagian tengah antara sudut sudut candi, sehingga mengesankan adanya delapan kelopak bunga teratai yang mekar dipermukaan atas kaki candi, di sekeliling badan candi yang berbentuk stupa. Hal ini penggambagan diagram mandala (Frederic 1995:37) dalam agama Buddha. Pada keempat sisi candi jiwa tidak terdapat tangga naik, akan tetapi dihalaman candi ini dikeempat sisinya terdapat hamparan bata yang disusun rapih membentuksebuah jalan yang mengitari kaki candi ( lihat foto 1 dan 2) jalan ini merupakan sebuah pradaksina-patha yaitu sebuah jalan untuk melakukan pradaksina, ritual dengan berjalan mengitari obyek pemujaan yang berada disebelah kanan pelaku searah dengan perputaran jarum jam. Dengan demikian candi jiwa merupakan sebuah candi untuk melakukan pemujaan (pradaksina).

b. Struktur Bangunan

Semua bangunan percandian baik yang berlatarkan agama buddha maupun hindu pada hakekatnya memiliki struktur yang dapat dibagi menjadi tiga bagian: (1)bagian bawah berupa kaki candi dan pondasi; (2) bagian tengah berupa badan candi; (3) bagian atas berupa atap candi. Ketiga bagian struktur bangunan candi tersebut pada agama buddha dan agama hindu biasanya dihubungkan dengan konsep keagamaan.

Temuan pada candi blandongan di batujaya adalah: struktur fondasi bata berbentuk segi empat atau bujur sangkar yang masif dan membentuk dinding kotak dengan bagian dalam yang diisi urugan, berupa tanah atau pecahanbata yang dipadatkan 
Struktur badan candi pada candi mengindikasikasi adanya ruangan atau bilik candi (garbha) didalam badan candi, sitemukan lantai bilik terbuat dari plesteran stuko yang dicampur batu kerikil dan sedikit lapisan lepa (perekat) yang masih menempel di pasangan bata.

Struktur Atap candi, hampir semua bangunan candi tidak meninggalkan bagian atas atu atapbangunan. Hanya ada satu bangunan yang masih menyisakan sedikit runtuhan yang berbentuk stupa. Sisa runtuhan bagian atas candi tersebut berupa pecahan bulatan kubah stupa (anda) bulatan kubah yang merupakan bagian dari stupa tersebut mempunyai garis tengah lingkaran alasnya 6 meter dan terbuat dari beton stuko dengan tebal sekitar $20 \mathrm{~cm}$. Permukaan luar kubah genta stupa tersebut permukaannyahalus, sedangkan permukaan dalamnya memperlihatkan teraan bekas tempelan susunan bata yang masif.
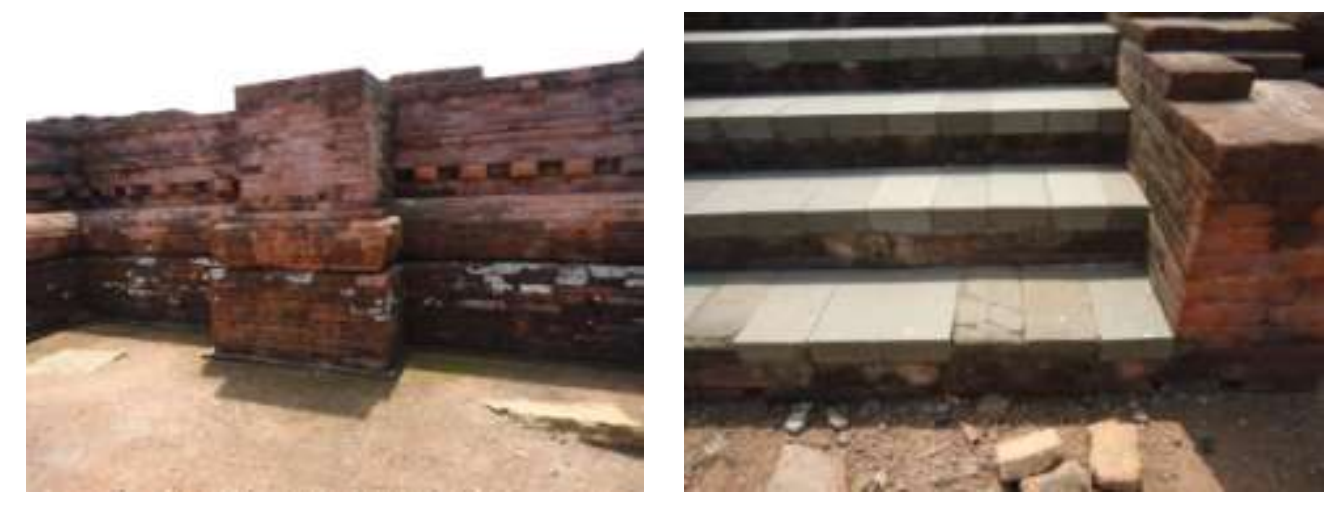

Gambar 1. Dinding setelah digali 1 meter dan tangga menuju stupa

c. Lingkungan

\section{Tata Guna Lahan}

Awalnya peneliti arkeologi menemukan sebuah gundukan tanah yang menyerupai sebuah gunung setelah diadakan penggalian ditemukan situs yang letaknya di tengah sawah pemukiman dan persawahan . Hasil penemuan dari para arkeologi dengan memperhatikan tatanan serta struktur perletakan susunan batu maka suatu pemukiman dan fasilitas berupa candi. Menurut metode Barnett (1982) teori ini digunakan untuk daertah pedesaan, Untuk pengendalian Perkembangan kawasan perlu menentukan cluster zoning (Planned Unit Development). Pada prinsipnya pengertian landuse adalah pengaturan penggunaan lahan untuk menentukan fungsi tertentu sehingga secara umum dapat menggambarkan keseluruhan bagaimana fungsi lahan pada kawasan tersebut. Hal lainnya adalah tata guna 
lahan dalam implikasinya dapat memudahkan pembagian zone dimana situs ditentukan sebagai obyek wisata keagamaan serta tempat ziarah sehingga perlu memperhatikan kemudahan dalam pencapaian menuju situs.

\section{Topografi}

Kawasan situs Candi Blandonga memliki topografi yang letaknya lebih rendah dari sungai Bekasi sehingga saat musim hujan air sungai naik maka sebagian lingkungan situs terendam untuk mengatasi permasalahan ini maka sekeliling candi dibuat cekukan untuk menampung air dan disudut sudut diletakan pompa untuk mengeluarkan air.
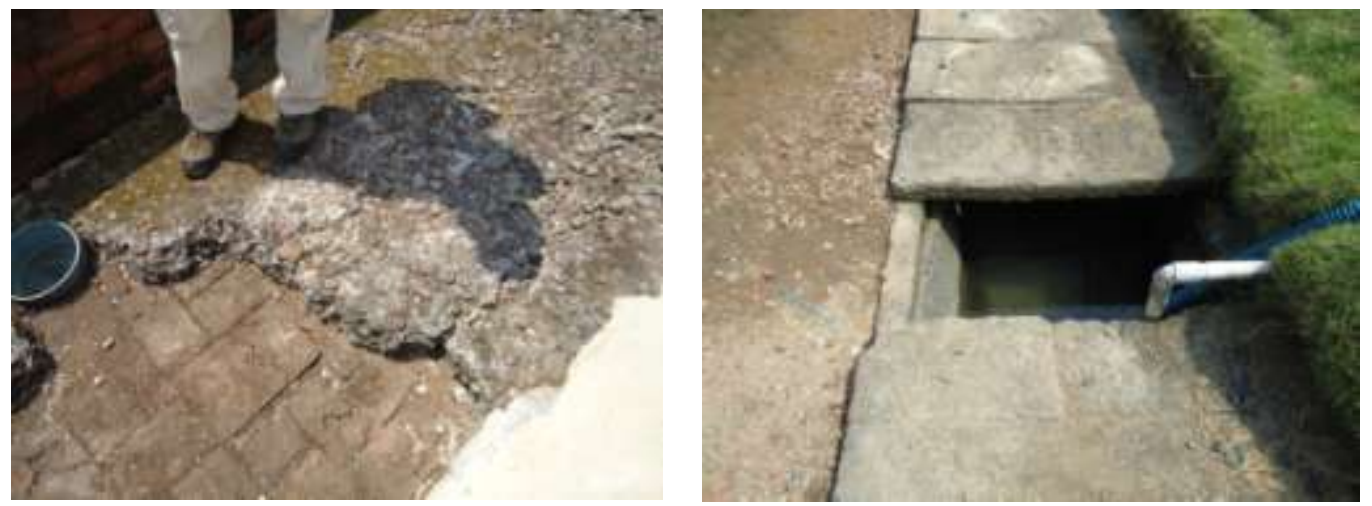

Gambar 2. Lubang saluran air dan saluran air sekeliling candi

\section{Pedestrian dan Parkir}

Pedestrian merupakan elemen penting hal ini terlihat lokasi situs terletak ditengah sawah yang jaraknya sangat jauh dari dari parkir. Menurut Wood (1979) perancangan pedestrian memberi kenyaman bagi pengguna dengan memperhatikan jangkauan dan perlindungan dari matahari dan hujan. Pedestrian pada kawasan situs jiwa dibuat pedestrian lebar 1.00 dan menggunakan material beton. Apabila musim banjir pedestrian tersebut akan terendam sehingga pada saat tertentu padestrian ini tidak dapat digunakan.

Fasilitas yang paling penting dalam bangunan publik adalah sarana parkir hal ini terlihat kawasan situs tidak memiliki tempat parkir sehingga banyak pengunjung yang memarkirkan kendaraannya dihalaman rumah penduduk disekitar situs. permasalahan dalam perencanaan sarana parkir harus membebaskan rumah disekitar situs hal inilah yang memberatkan pemda kabupaten kawarang. 


\section{Tanda tanda (signages)}

Papan petunjuk merupakan elemen visual yang semakin penting dalam perancangan kawasan seperti pintu gerbang, petunjuk jalan, arah ke suatu kawasan atau obyek . Perletakan tanda tanda masih belum teratur dan jelas seperti pintu utama ,penempatan titik titik serta arah akan mempengaruhi visual terhadap lingkungan candi. Pendekatan oleh Claus (1976) tentang masalah disai dimana penggunaan tanda tanda harus merefleksikan karakter kawasan situs dan memperhatikan jarak dan ukuran tanda tanda harus memadai dan diatur sedemikian rupa agar menjamin jarak pengelihatan agar tepat sasaran bagi pengunjung.

d. Langkah - langkah dalam penanggulangan banjir

Mengingat kawasan ini merupakan cagar budaya dimana terdapat 49 situs sehingga perlu memeliharaan terutaman di lokasi pakis jaya dimana terdapat Candi blandongan maka harus dilakukan penanggulangan banjir.

Candi Blandongan terletak diarea perumahan dan persawahan . setelah dilakukan penggalian letak candi blandongan memiliki titik terendahnya adalah 3 meter di bawah permukaan tanah. Apabila musim hujan dan debit air laut naik maka candi tersebut akan terendam sampai 1 meter dari permukaan tanah sesuai banjir didaerah tersebut yang letaknya rendah karena kerawang berdekatan dengan laut bahkan persawahan dan pemukiman disekitarnya akan mengalami banjir.

Upaya penanggulangan banjir maka dilakukan teknik penanggulangan sebagai berikut :

1. Pembuatan selokan disekitar candi dan memiliki kedalam 2 meter dari permukaan tanah. Adapun lebar selokan sekitar 1 meter

2. Dibuat tanggul atau gundukan tanah disekeliling candi yang memiliki ketinggian $50 \mathrm{~cm}$. Agar gundukan tersebut tidak longsor maka ditanami rumput dan tanaman menjalar

3. Membuat bak penampungan / kontrol disetiap sudut dimana memiliki ukuran $2 \mathrm{~m}$ x $2 \mathrm{~m}$ dengan kedalaman 2,5 meter gunanya untuk menampung air

4. Dibuat saluran dengan lebar $50 \mathrm{~cm}$ dimana air yang datang diarahkan ke penampungan.

5. Dengan menggunakan pompa pendorong air yang ada di bak penampungan dikeluarkan ke sawah . 
6. Adapun bak penampungan mengikuti konstruksisama seperti bak resapan air dimana keempat dindingnya dibuat dengan beton dan dasarnya diletakkan sabuk kelapa dan batu kerikil.

7. Bak penampungan ditutup dengan beton
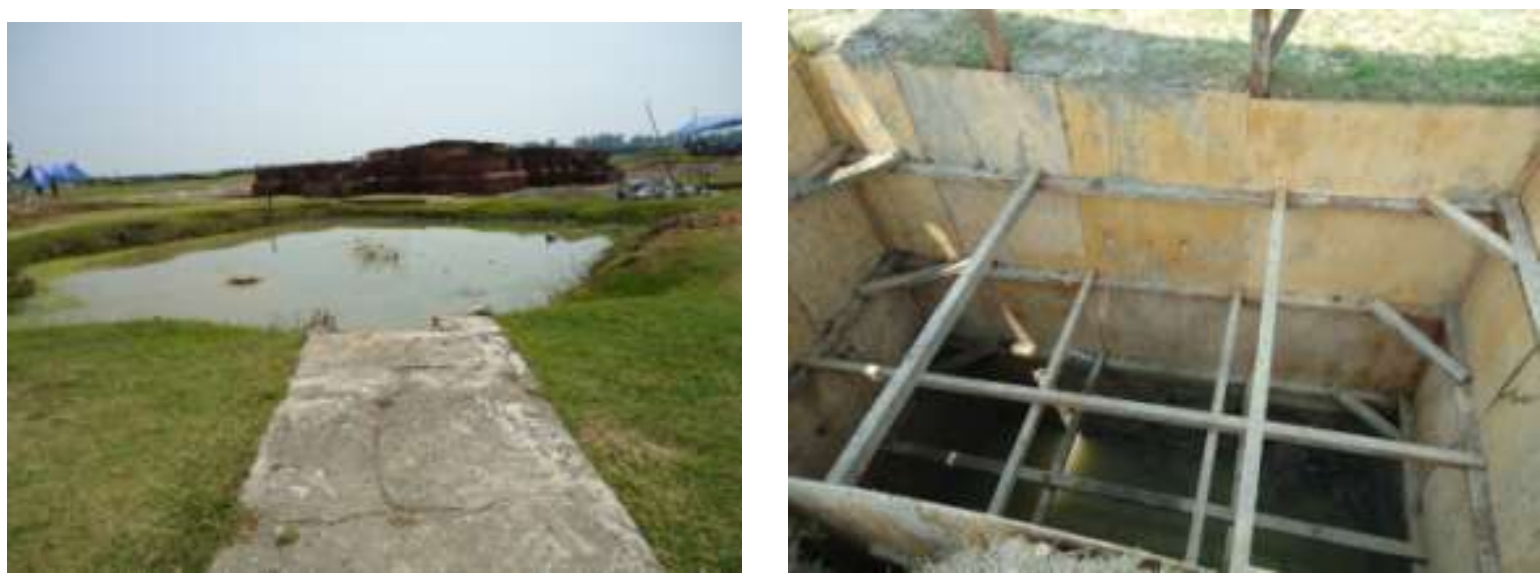

Gambar 3. Penampungan air Lubang penampungan air

e. Tanaman dan Lansekap

Pohon Body merupakan pohon keramat bagi umat budha dimana pohon yang ada disini merupakan sumbangan dari raja Thailand. Mengingat kawasan ini sangat panas sehingga diperlukan tanaman yang sifatnya dapat melindungi sehingga ditanam pohon beringin putih dan tanaman yg memiliki bunga disekeliling candi.

\section{KESIMPULAN}

Banyaknya situs yang belum dikembangkan sehingga diperlukan skala prioritas dalam memilih karena apabila situs akan dikembangkan maka muncullah konflik di masyarakat Batujaya dalam hal pembebasan tanah.

Kenyataannya terlihat pengembangan cagar budaya tidak memiliki master plan yang baik terlihat adanya perletakan lokasi museum jauh dengan situs dan pencapaiannya menuju situs harus melewati kawasan pemukiman.

Mengusulkan kepada pemda Karawang perlu adanya kemudahan akses menuju lokasi dengan memberikan jalur angkutan umum ke kawasan cagar budaya. 
Dengan banyaknya pengunjung yang datang ke cagar budaya akan meningkatkan pendapatan masyarakat seperti tumbuhnya warung, rumah makan dan toko, bengkel dan lainnya.

\section{DAFTAR PUSTAKA}

Edy Darmawan.IR.ME. Teori dan Implementasi Perancangan Kota, Badan Penerbit Universitas Diponegoro, Semarang. Cetakan tahun 2003.

Eko.Budihardjo, 1997,.Tata Ruang Perkotaan PT Alumni Bandung

Balai Pelestarian Cagar Budaya Serang. Kementrian Pendidikan dan Kebudayan Direktorat Jendral Kebudayaan.

Hasan.Prof Penulis Percandian Situs Batujaya dan Ketua Tim Survey dari Jurusan Arkeologi Fakultas Sastra Universitas Indonesia . 1985

Masterplan Pelestarian Pengembangan Kawasan Percandian Kabupaten Karawang Dinas Pariwisata dan Kebudayaan Propinsi Jawa Barat tahun 2011. 